EDUKACJA MIĘDZYKULTUROWA

\title{
„Psychopedagogiczne problemy edukacji i funkcjonowania człowieka - teoria i praktyka”. Zespół Problemowy nr 4: Edukacja międzykulturowa dla przyszłości. Od teorii do praktyki. Lublin, 26-27 listopada 2015 roku
}

Edukacja międzykulturowa dla przyszłości - od teorii do praktyki była przewodnim tematem sekcji problemowej zorganizowanej przez Zakład Edukacji Międzykulturowej UMCS w Lublinie w ramach Międzynarodowej Konferencji Naukowej pt. Psychopedagogiczne problemy edukacji i funkcjonowania człowieka - teoria i praktyka.

Konferencja odbyła się w dniach 26-27 listopada 2015 roku. Organizatorem był Wydział Pedagogiki i Psychologii UMCS, natomiast patronat honorowy objęli: Komitet Nauk Pedagogicznych PAN, Prezydent Miasta Lublin - Krzysztof Żuk, Wojewoda Lubelski - Wojciech Wilk, Marszałek Województwa Lubelskiego - Sławomir Sosnowski, a patronat medialny: Radio Lublin, TVP Lublin, „Kurier Lubelski”, Magazyn Psychologiczny „Charaktery”, Lubelskie - Smakuj Życie! W konferencji wzięło udział 350 osób - w tym: 170 przedstawicieli 41 uczelni wyższych z wiodących ośrodków akademickich w Polsce oraz 40 gości zagranicznych z 13 ośrodków naukowych z Ukrainy, Białorusi, Republiki Czeskiej i Turcji.

W ramach Konferencji w Instytucie Pedagogiki UMCS odbyła się podniosła uroczystość odsłonięcia pamiątkowej tablicy poświęconej śp. prof. zw. dr. hab. Januszowi Plisieckiemu. W wydarzeniu tym wzięli udział członkowie najbliższej rodziny Profesora. Odbyła się również promocja książki śp. prof. zw. dr. hab. Zbigniewa Pietrasińskiego pt. Dziennik komputerowy z [...], na którą przybyła żony Profesora - Maria Pietrasińska.

Dyskurs spotkania naukowego, omawiający problemy pedagogiki i psychologii w zakresie edukacji i funkcjonowania człowieka, był prezentowany 
w kilkunastu obszarach tematycznych zorganizowanych w ramach funkcjonujących Zakładów na Wydziale.

Tradycyjnie w pierwszej części konferencji odbyły się obrady plenarne. Referaty przedstawili: prof. zw. dr hab. Bogusław Śliwerski (Uniwersytet Łódzki) - Pedagogika realna wobec wirtualnego świata; prof. zw. dr hab. Jerzy Brzeziński (UAM w Poznaniu) - Teoria i praktyka. Uwarunkowania metodologiczne i etyczne; prof. zw. dr hab. Stefan M. Kwiatkowski (Akademia Pedagogiki Specjalnej im. M. Grzegorzewskiej w Warszawie) - Kształcenie dla przyszłości - między ambitnym wyzwaniem a utopia; prof. dr hab. Nella Nyczkało (Narodowa Akademii Nauk Pedagogicznych Ukrainy w Kijowie) - Problemy zawodowego rozwoju osobowości we wspótczesnych badaniach naukowców Ukrainy; prof. zw. dr hab. Maria Kielar-Turska (UJ) - Aktywność edukacyjna seniorów: specyfika motywów i funkcji; prof. zw. dr hab. Jerzy Nikitorowicz (Uniwersytet w Białymstoku) - Tożsamościowe skutki wielokulturowości: wielość kultur w jednym człowieku czy ekstremizm i separatyzm kultury?; prof. zw. dr hab. Stanisław Popek (UMCS) - Mechanizmy aktywności twórczej w świetle interakcyjnej teorii psychologicznej.

Drugą część stanowiły obrady zespołów problemowych odejmujących następujące zagadnienia:

- człowiek w środowisku pracy,

- nowe tendencje w pracy socjalnej - problemy kształcenia i działania,

- wieloaspektowy obraz współczesnej edukacji wczesnoszkolnej / możliwości i ograniczenia nowoczesnych technologii informacyjnych w dydaktyce,

- edukacja międzykulturowa dla przyszłości - od teorii do praktyki,

- pedagodzy, nauczyciele, instytucje oświatowe i ich wkład w edukację dzieci i młodzieży - przeszłość i teraźniejszość,

- sztuka - edukacja - animacja w XXI wieku,

- w poszukiwaniu jakości życia dziecka - dyskursy wokół opieki, wychowania i kształcenia,

- wychowanie resocjalizujące - utopia czy rzeczywistość?,

- edukacja nauczycieli - współczesne problemy i kierunki przemian,

- edukacja i psychospołeczne funkcjonowanie osób z niepełnosprawnością w realiach zintegrowanej Europy. Nowe szanse i stare bariery,

- psychospołeczne aspekty funkcjonowania rodziny,

- wychowanie wobec wyzwań współczesności,

- diagnoza neuropsychologiczna - dylematy i perspektywy rozwoju, 
- nowe metody i techniki w badaniach psychologicznych / trajektorie zmian - kontekst rozwojowy i edukacyjny,

- diagnoza i stymulacja zdolności i uzdolnień twórczych podstawą nowoczesnej modernizacji systemu edukacji / edukacyjny kontekst funkcjonowania człowieka,

- duchowość - niedoceniany aspekt psyche?

Problematyka poruszana w trakcie obrad w sekcji zorganizowanej przez Zakład Edukacji Międzykulturowej pod kierunkiem dr. hab. Mariusza Korczyńskiego, prof. nadzw., dotyczyła edukacji międzykulturowej dla przyszłości z uwzględnieniem zagadnień teoretycznych i szeroko pojętej praktyki. Panele dyskusyjne moderowali: prof. zw. dr hab. Jerzy Nikitorowicz, prof. zw. dr hab. Mirosław S. Szymański, dr hab. Mirosław Sobecki, prof. nadzw., i dr hab. Mariusz Korczyński, prof. nadzw.

Pierwszy prelegent dr hab. Piotr Petrykowski, prof. nadzw. (UMK w Toruniu) przedstawił referat pt. Pamięć początku - u źródeł tożsamości ku przyszłości. Zaznaczył w nim, że dziecko, wzrastając w danej kulturze i religii, przyswaja sobie pewne schematy, które stają się jego dziedzictwem kulturowym. W przyszłości, pomimo różnych zmian życiowych, łatwiej i szybciej można nabyte wzorce przywołać i odnowić.

Natomiast dr hab. Mirosław Sobecki, prof. nadzw. (Uniwersytet w Białymstoku) w wystąpieniu pt. Tożsamość społeczno-kulturowa w perspektywie autobiograficznej. Brunon Synak - Kaszub, Polak, Europejczyk zaprezentował postać profesora socjologii, wieloletniego prezesa Zrzeszenia Kaszubsko-Pomorskiego i przewodniczącego sejmiku pomorskiego. Nadmienił, że autobiograficzna relacja Brunona Synaka stanowi znakomitą egzemplifikację wielowymiarowej tożsamości społeczno-kulturowej. Ma ona istotny walor dydaktyczny: zwraca uwagę na znaczenie „wewnętrznej heterogeniczności”, nadaje wartość kategorii różnicy, stanowi przykład aktywnej postawy w kreowaniu tożsamości Verba docent - exempla trahunt. Jego działalność naukowa i społeczna ugruntowała swoją pozycję w edukacji międzykulturowej.

W referacie Poczucie tożsamości Romów a ich stosunek do edukacji - komunikat z badań na Stowacji dr Łukasz Kwadrans (Uniwersytet Śląski, Wydział Etnologii i Nauk o Edukacji w Cieszynie) podkreślił, że tożsamość romska jest stale przekształcana i podlega wzbogacaniu o elementy zaczerpnięte z innych kultur, np. poprzez edukację i kontakty z członkami innych społeczności, co może powodować zatracanie pewnych elementów tradycyjnej tożsamości romskiej na rzecz nowych. Zaakcentował także, że w grupie osób badanych istnieje niewielka świadomość odmienności kulturowej, a bardziej 
społecznej i socjalnej, pojawia się stereotypowe postrzeganie kultury własnej, akceptacja dla odmienności kulturowej - gadziowskiej inności oraz niska świadomość edukacyjna przy pozytywnej ocenie obowiązku szkolnego i wartości edukacji, a także brak możliwości pogłębiania wiedzy na temat grupy własnej. Badane osoby dorosłe negatywne odnosiły się do własnych doświadczeń szkolnych.

Dr Anna Odrowąż-Coates przedstawiła referat pt. Fatamorgana saudyjskiej przestrzeni społeczno-kulturowej kobiet. Plynne horyzonty socjalizacji, edukacji i emancypacji. Prezentując stroje noszone w miejscach publicznych przez kobiety - zasłonę zakrywającą twarz (niqab), czarną abaję, chustę zakrywającą włosy (hijab), i mężczyzn - tradycyjną togę (thawb) i czerwono-białą chustę (shemagh), zaznaczyła, że obyczaje i tradycja kulturowa nakładają na obywateli szereg restrykcji w życiu publicznym, objawiających się chociażby ścisłą segregacją płci, uniformizacją stroju czy podporządkowaniem rozkładu dnia rytuałom religijnym. Zwróciła też uwagę, że miejsce kobiet w sferze publicznej jest wyraźnie zdefiniowane, a właściwie zredukowane do niewyróżniania się z tłumu.

Polonijne placówki kulturalno-oświatowe we wschodniosyberyjskim regionie ekonomicznym przedstawiła mgr Ekatarina Kostiuczenko (UMCS w Lublinie). Zaznaczyła, że tworzone są one dla potomków osadników, którzy na początku XX wieku przymusowo lub dobrowolnie przybyli na tereny południowej Syberii. Prelegentka zwróciła uwagę, że od lat 90. XX wieku polskie organizacje pozarządowe takie jak: „Fundacja pomocy szkołom polskim na Wschodzie”, Stowarzyszenie „Wspólnota Polska”, Fundacja „Oświata polska za granicą” oraz „Fundacja pomocy Polakom na Wschodzie” aktywnie organizują naukę języka polskiego, kolonie językowe dla dzieci i młodzieży w Polsce i na Syberii, bezpłatną naukę na polskich uczelniach dla absolwentów polskich szkół, a także zespoły taneczno-wokalne propagujące tańce i pieśni polskie. Celem ich działalności jest podtrzymywanie polskiej tożsamości kulturowej.

Natomiast dr hab. Ewa Ogrodzka-Mazur prof. nadzw. i dr hab. Anna Szafrańska-Gajdzica (Uniwersytet Śląski, Wydział Etnologii i Nauk o Edukacji w Cieszynie) w referacie Kompetencje międzykulturowe w przygotowaniu zawodowym studentów - przyszłych nauczycieli. Badania porównawcze Polski $i$ Republiki Czeskiej w ramach projektu IRNet skoncentrowały swoją uwagę na kompetencjach kulturowych, w jakie należy wyposażyć przyszłych nauczycieli, odnosząc się do wyników własnych badań prowadzonych w ramach międzynarodowego projektu. 
Dr hab. Mariusz Korczyński, prof. nadzw. (UMSC w Lublinie) w referacie: Kluczowe kompetencje międzykulturowe a sukces zawodowy polskich emigrantów w Anglii zwrócił uwagę na najważniejsze kompetencje międzykulturowe i poziom ich przyswajania przez Polaków pracujących w Anglii, a także na ich subiektywne poczucie sukcesu. Prowadzone przez niego badania wykazały, że o sukcesie zawodowym decydują takie kompetencje jak: znajomość języka angielskiego, efektywność komunikacji, dowcip, elastyczność interpersonalna, radzenie sobie z uczuciami, adaptacja i elastyczność zachowań oraz możliwość dostosowania się do różnych kultur i umiejętność radzenia sobie ze stresem.

Dr Mariusz Samoraj (Uniwersytet Warszawski) omówił Edukację międzykulturowa dla przyszłości. Na przykładzie zajęć akademickich „Intercultural Dialogue" i programu Erasmus. Zaznaczył, że kompetencja ułatwiająca stawianie czoła różnicom kulturowym i zmianom kulturowym w społeczeństwach wielokulturowych jest równie istotna jak umiejętność czytania, pisania i liczenia. Jest alfabetem, który stanowi zwornik współczesnego świata i zasadniczy środek umożliwiający wykorzystanie wielorakich form, jakie może przybierać edukacja, jest też niezbędnym narzędziem przezwyciężania ,zderzenia ignorancji”. Wdrażanie tej kompetencji poparł przykładami własnych działań pedagogicznych realizowanych w ramach autorskich zajęć „Intecultural Dialogue”, w których uczestniczą studenci programu Erasmus, jak też cyklem wykładów i warsztatów artystycznych realizowanych w ramach wymiany wykładowców.

Dr hab. Barbara Grabowska (Uniwersytet Śląski, Wydział Etnologii i Nauk o Edukacji w Cieszynie), omawiając Makro i mikro uwarunkowania edukacji międzykulturowej, podała wśród wniosków, że dotychczasowe doświadczenia edukacji wielokulturowej nie stanowią już wystarczającej podstawy modelu edukacji odpowiadającego na aktualne potrzeby i oczekiwania, jednocześnie realia społeczne społeczeństw współczesnej Europy wymuszają wprowadzenie edukacji międzykulturowej, która jest nastawiona na poznawcze i wzajemne przenikanie się kultur, czerpanie z wartości innych kultur, zbliżenie ludzi i ich kultur - z poszanowaniem ich odmienności i tożsamości.

Doc. dr Iryna Hrynyk (Państwowy Uniwersytet Pedagogiczny im. I. Franki w Drohobyczu) przedstawiła referat: Psycholingwistyczne ekspertyzy indywidualnej tolerancji etnicznej. Zauważyła, że współczesna psycholingwistyka, zajmująca się psychologicznymi podstawami funkcjonowania języka - przyswajaniem i przetwarzaniem języka oraz wykorzystywaniem przez ludzki umysł), przenika się wzajemnie z socjolingwistyką - różnorodnością rela- 
cji języka do społeczeństwa i kultury. W efekcie język postrzega się z jednej strony - jako twór społeczny, wytworzony w wyniku społecznej interakcji, zaś z drugiej strony - jako specyficzny „nośnik” komunikowania, kreowania i podtrzymywania więzi społecznych, poznania rzeczywistości oraz kumulacji dorobku kulturowego.

Kolejna prelegentka mgr Katarzyna Dąbrowska (UMCS w Lublinie) przedstawiła referat: Wrażliwość międzykulturowa studentów pedagogiki w aspekcie ich przyszłej pracy dydaktyczno-wychowawczej. Zaakcentowała potrzebę kształtowania wrażliwości międzykulturowej wśród przyszłych pedagogów. Opierając się na własnych badaniach, nadmieniła, że ważne jest, aby nabyli oni kompetencje komunikacyjne, opierające się na umiejętności: słuchania, dostrzegania i współdziałania, zauważania i akceptowania inności oraz umiejętność rezygnowania z podejścia etnocentrycznego na rzecz etnorelatywistycznego. Zaznaczyła, że kompetencje te kształtują szacunek i tolerancję dla niejednoznaczności, kreują postawy elastyczności i otwartości oraz wzmacniają świadomość obywatelską.

Prof. zw. dr hab. Halina Rusek (Uniwersytet Śląski, Wydział Etnologii i Nauk o Edukacji w Cieszynie) w referacie pt. Odtwarzanie tożsamości regionalnej jako wyzwanie dla edukacji poruszyła niezwykle aktualny temat dotyczący różnorodnych inicjatyw lokalnych mających na celu odtwarzanie tożsamości regionalnej na Śląsku oraz problemów wynikających z podejmowanych działań. Prelegentka zwróciła uwagę na wyzwania stojące przed edukacją dzieci i młodzieży w tym zakresie.

Dr hab. Agata Cudowska, prof. nadzw. (Uniwersytet w Białymstoku), zaprezentowała referat: Doświadczanie Innego jako wzbogacanie aksjologicznej przestrzeni wychowania, w którym zaznaczyła, że warunkiem niezbędnym wzbogacania aksjologicznej przestrzeni wychowania jest między innymi: uświadomienie dialogiczności słowa, uwrażliwianie na wartości, przekazywanie wiedzy o warunkach niezbędnych do urzeczywistniania się odpowiedzialności, wolności i sprawiedliwości, dowartościowanie spotkania w procesie wychowawczym, gotowość wychowawcy do kształtowania aspektów aksjologicznych, chęć przezwyciężania w wychowanku poczucia lęku, osamotnienia, czy wykluczenia.

W swoim wystąpieniu dr hab. Dorota Misiejuk (Uniwersytet w Białymstoku) pt. Sytuacja wychowawcza i jej opis w kontekście wyzwań różnicy kulturowej, zwróciła uwagę: aby dziecko mogło się rozwijać, musi mieć odpowiednią sytuację wychowawczą w aspekcie jego tożsamości kulturowej, co jest niezbędnym warunkiem w kształtowaniu się osobowości. Podmioty uczest- 
niczące w tym spotkaniu powinny posiadać pełną świadomą konsekwencji swoich działań oraz być otwarte i gotowe na doświadczenia pojawiające się spontanicznie. Sprzyjać temu ma między nimi odpowiedni dobór treści i metod oddziaływań.

W kolejnym wystąpieniu dr Aniela Różańska (Uniwersytet Śląski, Wydział Etnologii i Nauk o Edukacji w Cieszynie) w referacie pt. Międzykulturowe konteksty szkolnej edukacji religijnej poruszyła problemy szkolnej edukacji religijnej w Polsce, Republice Czeskiej, na Słowacji i Węgrzech. Swoje rozważania oparła na wynikach badań własnych. Szczególną uwagę zwróciła na religijność i tożsamość religijną badanej młodzieży, poczucie religijności oraz udział w szkolnej edukacji religijnej.

Natomiast dr Janina Urban (Uniwersytet Śląski, Wydział Etnologii i Nauk o Edukacji w Cieszynie) przedstawiła referat Narodowość i obywatelstwo $w$ treściach ksztatcenia szkót dla mniejszości $i$ większości oraz identyfikacjach ich uczniów w krajach Grupy Wyszehradzkiej, w którym odniosła się do prowadzonych badań w Polsce, Republice Czeskiej, na Słowacji i Węgrzech. Zaznaczyła, że treści narodowe i obywatelskie zajmują w szkołach dla mniejszości i dla większości różną pozycję w hierarchiach zadań szkoły, jednak we wszystkich wyróżnionych środowiskach treści narodowe w szkołach dla mniejszości zajmują wyższą pozycję niż obywatelskie, podczas gdy w szkołach dla większości odwrotnie.

Ostatni referat wygłosiła mgr Małgorzata Majerek (UMCS w Lublinie). Dotyczył on analizy badań: Wrażliwość międzykulturowa osób wyczynowo uprawiających sport. Prelegentka zwróciła uwagę, że wrażliwości międzykulturowa w grupie osób wyczynowo uprawiających sport i nieuprawiających jest na przeciętnym poziomie. Spośród potencjalnych czynników różnicujących wrażliwość międzykulturową tylko wiek i pochodzenie miały istotny wpływ. Zaznaczyła także, że była to zależność jedynie na poziomie niektórych podskal: dla wieku - „przyjemność z interakcji” i „uwaga w interakcji”, a dla pochodzenia - „przyjemność z interakcji”. Osoby starsze i pochodzące z miasta charakteryzowały się wyższą wrażliwością międzykulturową.

Również zaprezentowany został poster pt. Wielokulturowość Lubelszczyzny - aktualne wyzwania wpisujący się w tematykę badawczą prowadzoną przez Zakład Edukacji Międzykulturowej UMCS. Autorką i prelegentką posteru była dr Agata Świdzińska. Przedstawiony przez nią poster prezentował dane liczbowe dotyczące obecności cudzoziemców na terenie województwa lubelskiego. W graficzny sposób ujęte zostały aktualne zmiany w przestrzeni społecznej województwa wywołane migracjami. Przedstawiono zatem li- 
czebność studentów cudzoziemskich studiujących na dziewięciu lubelskich uczelniach oraz i rozmieszczenie ośrodków dla cudzoziemców (uchodźców). Autorka zaznaczyła, że wzrost różnorodności kulturowej jest wyzwaniem dla intensywnej pracy edukacyjnej w sferze międzykulturowych kontaktów, co w dużej mierze podejmują organizacje pozarządowe zajmujące się integracją oraz pomocą cudzoziemcom.

Spotkanie w Sekcji zakończył krótki panel dyskusyjny, po którym dr hab. Mariusz Korczyński, prof. nadzw., podziękował wszystkim za udział i merytoryczne obrady. Zauważył, że aktualnie dostrzegalna staje się potrzeba zmiany stosunku do wielokulturowości i zachęcił do dalszych eksploracji naukowych.

Oficjalnego zamknięcia Konferencji Wydziałowej dokonał dziekan - prof. zw. dr hab. Ryszard Bera, dziękując wszystkim uczestnikom za udział, i zaprosił na kolejne spotkanie. 